\title{
$\gamma$-Glutamyltranspeptidase in the Rat Liver after Portacaval Shunt
}

\author{
J. P. COLOMBO, (44) E. PEHEIM, AND C. BACHMANN \\ Department of Clinical Chemistry, Inselspital, University of Berne, Berne, Switzerland \\ EDITH MÜLLER \\ Institute of Anatomy, University of Zürich, Zürich, Switzerland \\ J. BIRCHER \\ Department of Clinical Pharmacology, University of Berne, Berne, Switzerland
}

\begin{abstract}
Extract
$\gamma$-Glutamyltranspeptidase (GGTP) activity was studied in livers of rats submitted to an end-to-side portacaval shunt (PCS) and in developing animals. To correlate the evolution of the enzymatic activity measured in vitro, histochemical techniques were used to localize enzyme activity in liver tissue. The GGTP activity in the adult rats was low and amounted to $2.0 \pm 0.1 \mu \mathrm{mol} / \mathrm{min} / \mathrm{g}$. During fetal development the enzyme activity rose beginning on the 15th gestational day from $630 \pm 97$ to $1,058 \pm 20$ on the first postnatal day. Then the values declined and reached nearly adult values from the 10th postnatal day.

After PCS the GGTP activity exhibited a three- to sixfold increase $(130 \pm 69$ to $371 \pm 131)$ as compared with unoperated adult controls $(53 \pm 13)$. The highest levels corresponded to those observed between the $3 \mathrm{rd}$ and 5 th postnatal day in the developing rats.

The histochemistry of GGTP in the fetal and newborn liver showed a regular distribution of the enzyme as a fine deposit in the hepatocytes throughout the whole tissue. Ten days after birth the activity was low, at the same level as in the adult rat. In the period after PCS hepatocytes began to show signs of enzymatic activity at the periphery of the hepatic lobules, which subsequently spread through the whole lobules. The increase of GGTP activity after PCS equaled the activity found in fetal animals. That correlated well in both groups with the reappearance of histologically demonstrable enzyme activity in hepatocytes.
\end{abstract}

\section{Speculation}

The consequences of portacaval shunt might be associated with the derepression of an enzyme normally present only in fetal and neonatal rat liver. Since GGTP plays a role in the $\gamma$-glutamyl cycle, and is responsible, supposedly, for the transport of amino acids into the cell, it may be that in fetal liver and after PCS augmented cellular amino acid transport is an expression of growth and transformation processes.

The end-to-side PCS in the rat represents an appropriate model to study experimental hyperammonemia $(7,15)$ because of the shunting of portal blood to the systemic circulation. In addition to hyperammonemia, portacaval shunting leads to marked changes of the quantity and composition of the blood reaching the liver. The consequences of the shunt operation are therefore multiple. Encephalopathy, testicular atrophy, and changes in body and liver weight have been reported $(1,15)$. The metabolism of bile salts and of certain amino acids seems to be affected as well $(14,24-26)$.

These significant morphologic and functional changes are likely to be interpreted as a consequence of shunt-induced alterations in the metabolic stimulation of the liver. Despite considerable work in this field, no common denominator has been found to define the underlying hepatic process of the transformations induced by PCS. To our knowledge the specific hypothesis has not been tested of whether some of the consequences of PCS on hepatic metabolism might be considered as a regression of the liver cell function to a more immature or embryonal state. A study of biochemical features which differ significantly in fetal and adult animals might shed light on this problem. Differences have been noted for urogenesis, glycogenolysis, gluconeogenesis, and fatty acid synthesis $(8,9)$. In addition to these overall metabolic reactions, differences were found in the activity of enzymes such as aldolase, hexokinase, phosphorylase, pyruvate kinase, and in the pattern of some of their isoenzymes (16).

Preliminary experiments have shown that $\gamma$-glutamyltranspeptidase (GGTP, $\gamma$-glutamyltransferase, E.C. 2.3.2.2) in the liver behaved the same after PCS as during fetal development (5). We considered therefore this enzyme to be a suitable parameter for this kind of study. To correlate the evolution of the enzymatic activity measured in vitro, histochemical techniques were used to localize enzyme activity in liver tissue.

\section{METHODS AND MATERIALS}

The PCS experiments were carried out on a strain of SPFSprague-Dawley male rats bred in a closed colony (39). Free access to standard rat food (Altromin R-300) and water was allowed. Coprophagy was not prevented. In the developing animals the fetal age was assessed from the date of conception, the normal gestation period being 22 days. The date of conception of pregnant rats was determined by the appearance of vaginal plugs. The general conditions for maintaining the animals and the techniques of portacaval shunting and of sham operation have been described earlier (15). Ten, 13, 20, and 30 days after PCS the animals were killed by decapitation. To get enough material for measurements in fetal rats, three to four livers of the same embryonal stage were pooled. The liver was removed and processed immediately. For enzyme analysis a $10 \%$ hemogenate $(\mathrm{w} / \mathrm{v})$ was prepared in $0.2 \mathrm{M}$ saccharose. For the microsomal fraction the homogenate was spun in a refrigerated centrifuge for $30 \mathrm{~min}$ at $11,000 \times \mathrm{g}$. The pellet was discarded. The supernatant was recentrifuged for $1 \mathrm{hr}$ at 
$105,000 \times g$. The pellet was resuspended for enzyme analysis in 1.0 $\mathrm{mI} 0.25 \mathrm{M}$ saccharose containing $1 \mathrm{mmol}$ EDTA. Glucose-6-phosphatase (EC. 3.1.3.9) was determined according to the method of Baginsky et al. (3). The phosphate liberated in the reaction was analyzed with the malachite green reaction (28).

For the determination of DNA, the liver was homogenized 1:10 $(\mathrm{w} / \mathrm{v})$ with $5 \%$ trichloroacetic acid and incubated in capped tubes for $30 \mathrm{~min}$ at $100^{\circ}$. The mixture was then cooled in ice water and diluted further 1:10 with $5 \%$ trichloroacetic acid. After centrifugation the supernatant was incubated for $20 \mathrm{hr}$ at $25^{\circ}$ in sealed caps with diphenylamine-acetaldehyde reagent. The color was read at $600 \mathrm{~nm}$. A blank and standards of different concentrations, using salmon sperm DNA, were carried through the whole procedure. The protein content was determined by the method of Lowry et al. (20)

The activity of $\gamma$-GGTP was measured using $\gamma$-glutamyl- $p$ nitroanilid as substrate (35). All tissues used for biochemical measurements were also used for histochemical examination. In addition, human fetal liver $(10,17$, and 18 weeks of gestation) and onc liver from a 3-month-old child (40) were examined. The early human fetal stages were obtained by uterotomy during legal interruptions. Cryostat sections of $8-\mu \mathrm{m}$ were mounted on slides, air-dried for $1 \mathrm{hr}$ at $4^{\circ}$, and incubated at $25^{\circ}$ in freshly prepared solution as indicated by the method of Rutenberg et al. (33) using the substrate $\gamma$-glutamyl-4-methoxy-2-naphthylamide (41).

All data are expressed as means and standard deviation (28). Differences were calculated with the Student $t$-test. $P$ values above 0.05 were considered not significant. Each group after PCS was statistically compared with the control group and against each other. The pooled livers of fetal rats counted as one measurement.

\section{RESULTS}

\section{GGTP IN DEVELOPING RAT}

GGTP displayed a low activity in the adult rat liver (Table 1). During fetal development the enzyme activities rose steadily to peak values at the first postnatal day. They were significantly higher than in the adult liver. After the first postnatal day the values decreased and reached nearly adult values from the 10th postnatal day on. These changes were observed whether the en zyme activity was referred to wet weight or to the DNA content. It has been shown that GGTP activity is found in the cytoplasma and in the microsomal fraction (34). Changes in enzyme development should therefore also be demonstrable in this particular fraction. The activity measured in the microsomal fraction paralleled that observed when the whole liver homogenate was used. Glucose-6-phosphatase was measured as a microsomal marker

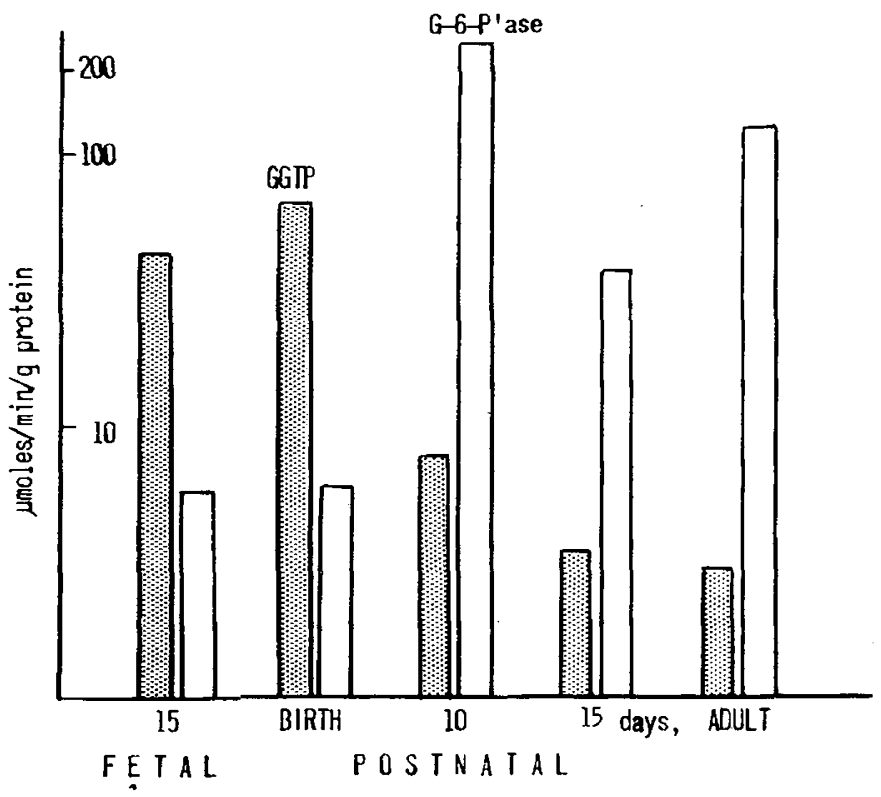

Fig. 1. Activity of $\gamma$-glutamyltranspeptidase $(G G T P)$ and glucose6-phosphatase (G-6-P'ase) in the microsomal fraction of fetal and postnatal rat livers.

enzyme. The activity was lower in fetal life and at birth, but increased by the 10th day to adult values (Fig. 1).

The DNA content of the liver was significantly higher in the fetal and young animals. The highest concentrations were observed in the fetus, declining regularly in postnatal life to adult values.

\section{GGTP AFTER PCS}

In shunted animals, a decrease in liver and body weight during the first days after the operation has been a general experience in this and other laboratories $(1,7,15,19)$. This implies a PCS which functions well. The changes have also been observed in this series (Table 2) and were of the same order of magnitude as described in former studies $(7,15)$. GGTP activity after PCS rose significantly compared with that of adult control animals (Table 3). It increased up to the 13th day; minimum values were observed at day 20 , with a subsequent increase at 30 days. The higher levels corresponded to those observed between the 3rd and 5th postnatal day in the developing animal. The sham-operated animals exhibited a slight elevation of GGTP activity, which, however, was still lower than that observed after PCS.

The DNA content per gram fresh weight of the liver increased

Table 1. Activity of $\gamma$-glutamyltranspeptidase $(G G T P)$ and DNA content in liver tissue of developing rat

\begin{tabular}{|c|c|c|c|c|c|c|c|c|}
\hline DNA, $\mathrm{mg} / \mathrm{g}^{3}$ & $11.79 \pm 2.37$ & $9.06 \pm 0.95$ & $4.56 \pm 0.80$ & $5.27 \pm 0.74$ & $4.01 \pm 0.41$ & $3.70 \pm 0.40$ & $3.84 \pm 0.44$ & $\begin{aligned} 2.0 \pm 0.15 \\
\leftarrow P^{4}<0.001\end{aligned}$ \\
\hline $\begin{array}{l}\mathrm{GGTP}, \mu \mathrm{mol} / \\
\mathrm{min} / \mathrm{g}^{3}\end{array}$ & $630.0 \pm 97.8$ & $675.1 \pm 192.3$ & $1,058 \pm 20$ & $558 \pm 70$ & $\begin{array}{l}216.0 \pm 132.3 \\
\leftarrow P<0.001^{4}\end{array}$ & $\begin{array}{c}48.0 \pm 26.1 \\
\text { n.s. }\end{array}$ & $\begin{array}{c}51.8 \pm 9.2 \\
\text { n.s. }\end{array}$ & $53 \pm 13.5$ \\
\hline
\end{tabular}

\footnotetext{
1 Day of gestation.
}

${ }^{2}$ Numbers in parentheses indicate number of fetal livers used for one measurement.

${ }^{3}$ Per gram wet weight, mean $\pm \mathrm{SD}$.

${ }^{4} P$ values indicate the significance of each day $v s$, adult animals. If the $P$ values were similar in the different groups only one value was reproduced $(\leftarrow P)$.

${ }^{5}$ Not significant. 
after PCS to the same order of magnitude as observed in the 5th to 10 th day of postnatal life. The adult control animals exhibited DNA concentrations in the same range as found in the shamoperated animals.

\section{HISTOCHEMICAL FINDINGS}

The distribution of GGTP activity in the rat liver undergoes characteristic changes in postnatal life as well as after PCS. In the fetal and newborn liver a regular distribution of the enzyme throughout the whole tissue can be observed (Fig. 2). All hepatocytes show a fine reaction deposit; most of the activity is found in the bile capillaries. In the postnatal period enzyme activity gradually becomes localized towards the periportal area of the lobuli (Fig. 3). Ten days after birth the activity was as low as that in the adult rat (Fig. 4). In the period after PCS hepatocytes began to show first signs of enzymatic activity at the periphery of the hepatic lobules (Fig. 5). Subsequently, the activity spread in a regular way through the lobules toward the central portal vein. The results of semiquantitative evaluation of enzyme disappearance in postnatal life and enzyme onset after portacaval shunt correspond to the biochemical findings received with measurements at the same periods.

The pattern of the GGTP activity in human fetal liver is identical with that found in rat fetal liver (Fig. 6): regular distribution of the enzyme in all hepatocytes and particularly in bile capillaries. The liver of the 3-month-old child showed only low reaction deposits of the enzyme activity confined to the hepatocytes at the periphery of the hepatic lobules and in the bile duct epithelia (Fig. 7). This enzyme pattern corresponds to postnatal developmental stagés of enzyme activity in the rat liver.

Table 2. Changes in body and liver weight in rats subjected to portacaval shunt (PCS) operation ${ }^{1}$

\begin{tabular}{lrrrrr}
\hline $\begin{array}{c}\text { Experimental } \\
\text { group }\end{array}$ & $n$ & $\begin{array}{c}\text { Pre- } \\
\text { operative } \\
\text { weight, g }\end{array}$ & $\begin{array}{c}\text { Body weight } \\
\text { after } \\
\text { PCS, g }\end{array}$ & $\begin{array}{c}\text { Days } \\
\text { after } \\
\text { operation }\end{array}$ & $\begin{array}{c}\text { Liver } \\
\text { weight, g }\end{array}$ \\
\hline PCS & & & & & \\
Group I & 5 & $256 \pm 13$ & $210 \pm 15$ & 10 & $4.7 \pm 0.6$ \\
Group II & 5 & $268 \pm 7$ & $225 \pm 12$ & 13 & $5.1 \pm 0.7$ \\
Group III & 5 & $272 \pm 17$ & $227 \pm 31$ & 20 & $5.4 \pm 0.9$ \\
Group IV & 5 & $264 \pm 26$ & $189 \pm 19$ & 30 & $3.7 \pm 0.8$ \\
Sham-operated & 3 & $257 \pm 16$ & $250 \pm 17$ & 13 & $8.9 \pm 1.1$ \\
Unoperated & 10 & $265 \pm 33$ & & & $9.4 \pm 1.2$ \\
$\quad$ controis & & & & & \\
\hline
\end{tabular}

${ }^{1}$ Mean $\pm \mathrm{SD}$.

\section{DISCUSSION}

DNA

The DNA contents per unit liver weight of fetal and adult rat liver found in our observations were in agreement with those recently published by Wehling et al. (36). The DNA content after PCS compared well with that found in the liver of the early postnatal stages. The increased DNA content per unit liver weight after PCS shows that more cells are present per volume of liver tissue. The number of hepatocytes may be calculated based on the morphometric measurements of Weibel et al. (37). They estimated that the number of hepatocytes on the basis of counted cell nuclei to be $169 \times 10^{6} / \mathrm{ml}$ tissue for adult liver. The ratio of DNA content per gram wet weight of PCS liver to that of control livers yields the number of cells present in PCS liver. It must be assumed that the ratio of extrahepatocytic cells and hepatocytes remains constant and that the specific gravity of live tissue is 1 . The number of cells per gram of tissue would then amount in PCS liver from $356 \times 10^{6}$ (10th day) to $280 \times 10^{6}$ (30th day). The initial loss of liver mass is therefore due more to a reduction in cell size rather than in cell number (13). It can not be decided, however, whether the elevated amount of DNA is due to an augmented production of new, but smaller and younger hepatocytes, or to shrinking of the prevailing cells, or to both. Cell turnover studies by Rubin (31) in shunted animals suggest that the liver of the shunted rats may be composed of younger cells than that of normal rats.

GGTP

GGTP catalyzes the transfer of the $\gamma$-glutamyl part of peptides to $\alpha$-aminoacids or other peptides. The most common substrate is glutathione (21).

In the adult rat appreciable enzyme activity has been found in kidney and intestine (35). In the liver it has been demonstrated by histochemical techniques in Kupffer cells, endothelium of periportal vessels, and bile duct epithelium, whereas virtually no activity could be observed in hepatocytes (33).

High activities of GGTP were found in livers of developing experimental animals and also of the human fetus and neonate. This phenomenon may be correlated to the observation that cord blood and plasma of human neonates exhibit higher activities of GGTP compared with adult plasma (29). The two- to six-fold increase of GGTP activity after PCS equaled that found in fetal animals. It correlated well with the reappearance of histologically demonstrable enzyme activity in hepatocytes.

The microscopical anatomy of the liver of shunted rats looks grossly rormal $(1,19)$. The generally recognized minor morphologic alterations of the liver tissue do not appear to be sufficient to explain the observed enzymatic changes. These may rather be

Table 3. Activity of $\gamma$-glutamyltranspeptidase $(G G T P)$ and $D N A$ content in rat liver tissue in unoperated controls, sham-operated animals, and in four groups 10,13,20, and 30 days after portacaval shunt operation

\begin{tabular}{|c|c|c|c|c|c|c|}
\hline & 10th, $n=5$ & 13 th, $n=5$ & 20th, $n=5$ & 30th, $n=5$ & $\begin{array}{c}\text { 13th } \\
\text { (sham operated), } \\
n=3\end{array}$ & $\begin{array}{c}\text { Adults } \\
\text { (unoperated } \\
\text { controls), } \\
n=10\end{array}$ \\
\hline $\mathrm{DNA}, \mathrm{mg} / \mathrm{g}^{1}$ & $4.2 \pm 0.65$ & $3.48 \pm 0.55$ & $3.66 \pm 0.40$ & $\begin{array}{l}3.34 \pm 0.73 \\
\leftarrow P<0.01^{2}\end{array}$ & $\begin{array}{c}2.60 \pm 0.10 \\
\text { n.s. }^{3}\end{array}$ & $2.0 \pm 0.15$ \\
\hline $\mathrm{GGTP}, \mu \mathrm{mol} / \mathrm{min} / \mathrm{g}^{1}$ & $\begin{array}{c}203.3 \pm 59.7 \\
P<0.001\end{array}$ & $\begin{array}{c}371.6 \pm 131.3 \\
P<0.01\end{array}$ & $\begin{array}{c}130.5 \pm 69.1 \\
P<0.01\end{array}$ & $\begin{array}{c}301.5 \pm 183.9 \\
P<0.01\end{array}$ & $\begin{array}{c}67.7 \pm 34.2 \\
\text { n.s. }\end{array}$ & $53 \pm 13.5$ \\
\hline
\end{tabular}

${ }^{1}$ Per gram wet weight, mean $\pm \mathrm{SD}$.

${ }^{2} P$ values indicate significance $v s$. unoperated controls. If the $P$ values were similar in the different groups only one value was reproduced $(\leftarrow P)$.

${ }^{3}$ Not significant. 


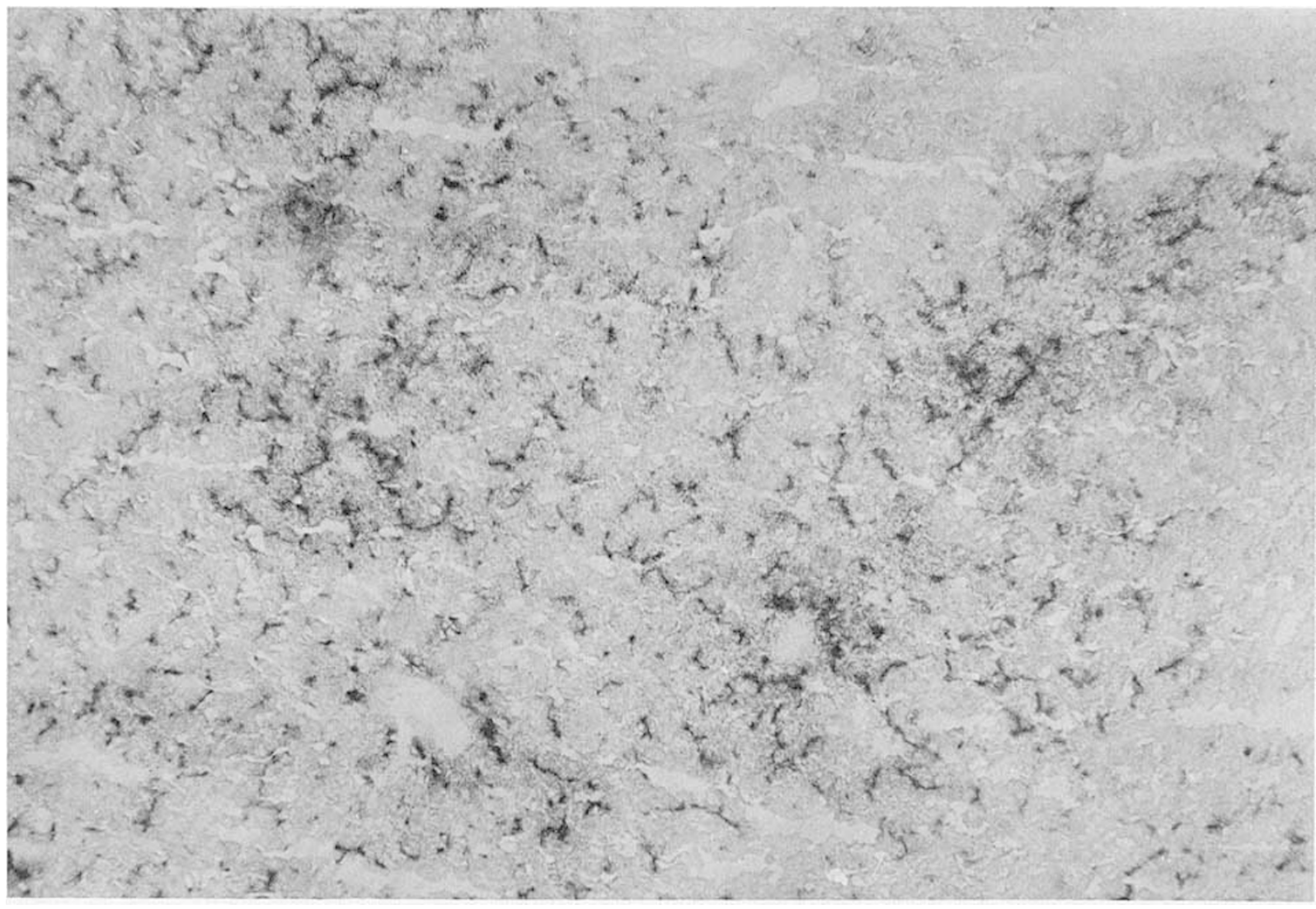

Fig. 2. Histochemical distribution of $\gamma$-glutamyltranspeptidase in newborn rat liver $\left(\begin{array}{ll}\times & 57\end{array}\right)$.

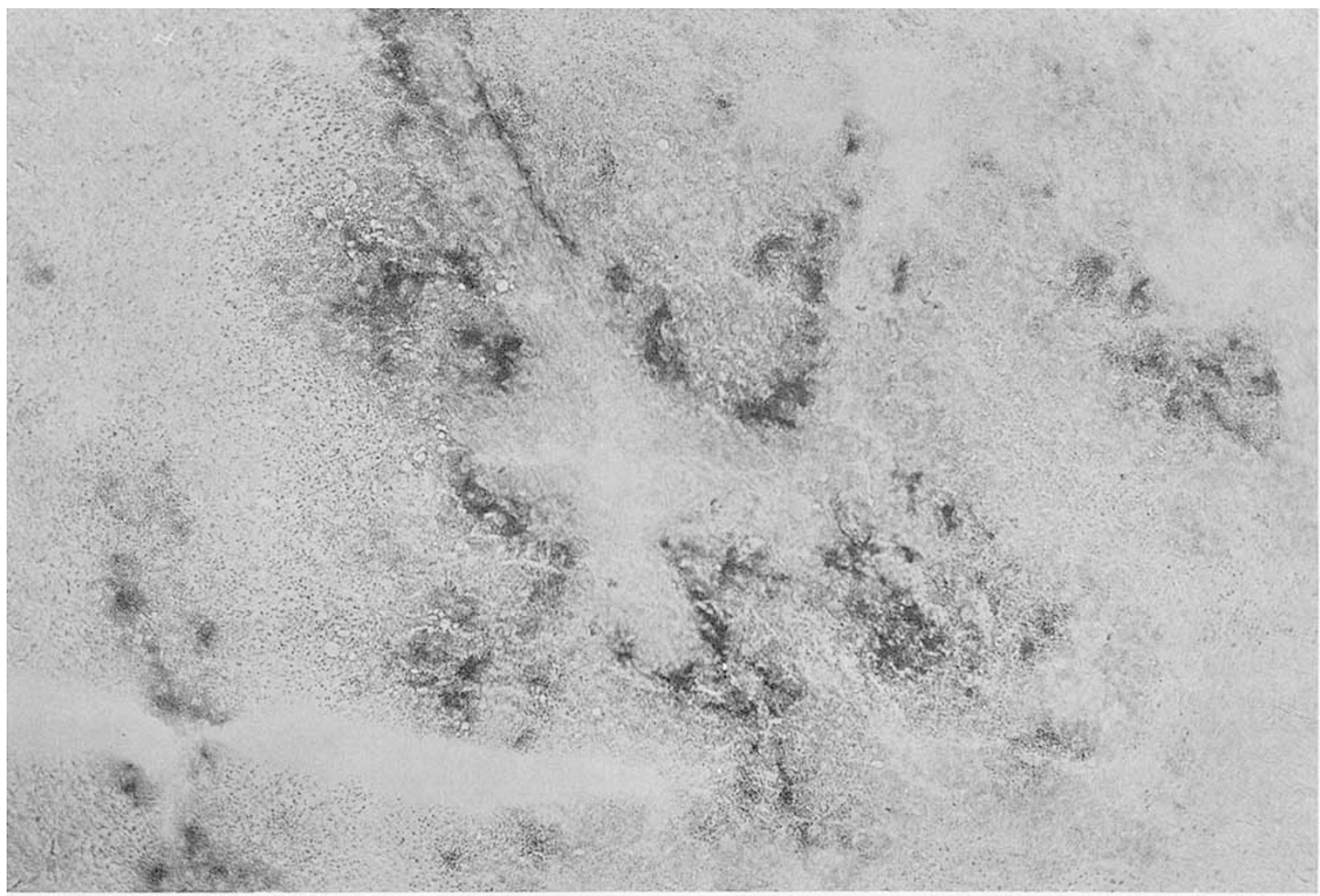

Fig. 3. Histochemical distribution of $\gamma$-glutamyltranspeptidase in the rat liver of the 5 th postnatal day $(\times 57)$. 


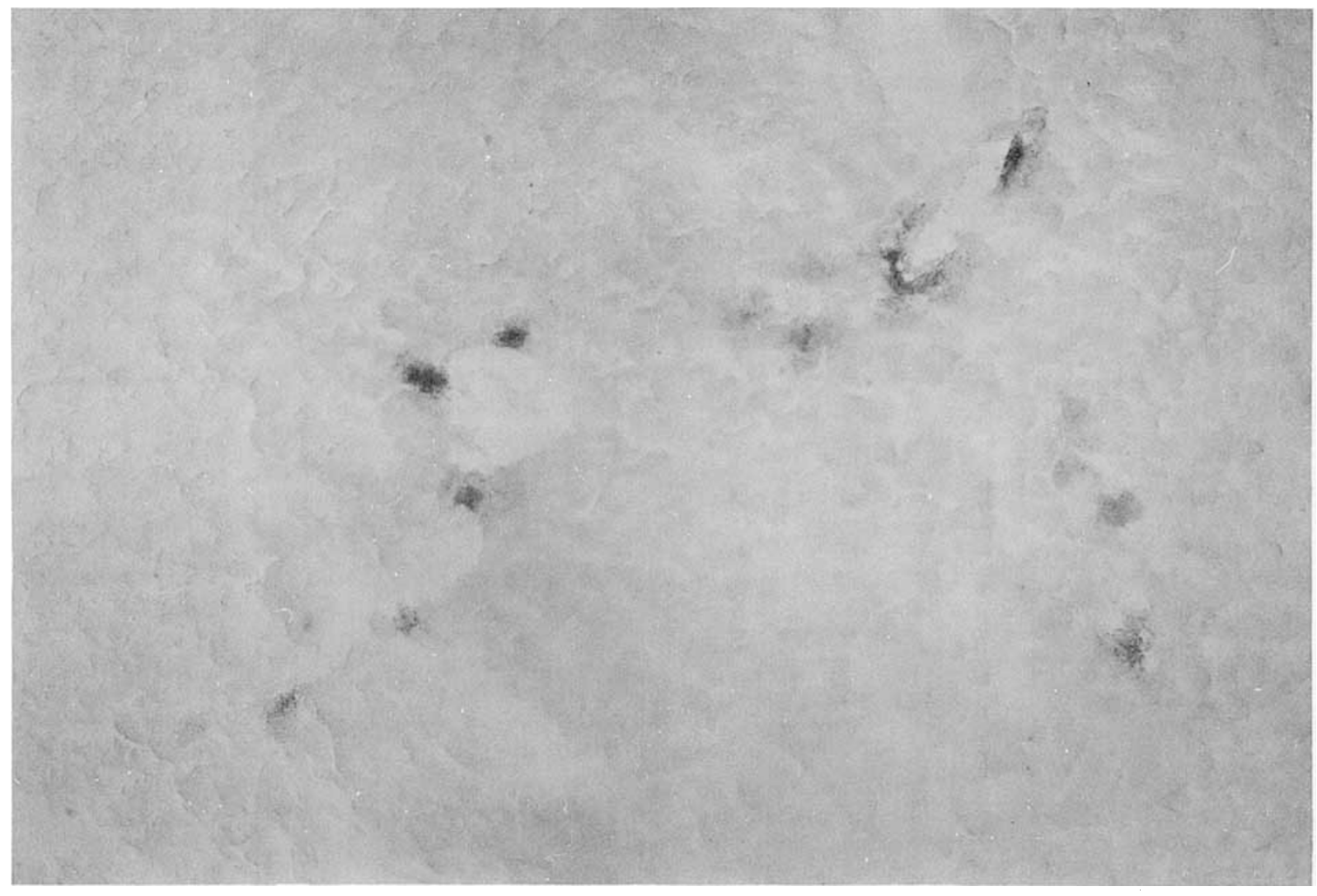

Fig. 4. Histochemical distribution of $\gamma$-glutamyltranspeptidase in the adult rat liver $\left(\begin{array}{l}\times \\ 94\end{array}\right)$.

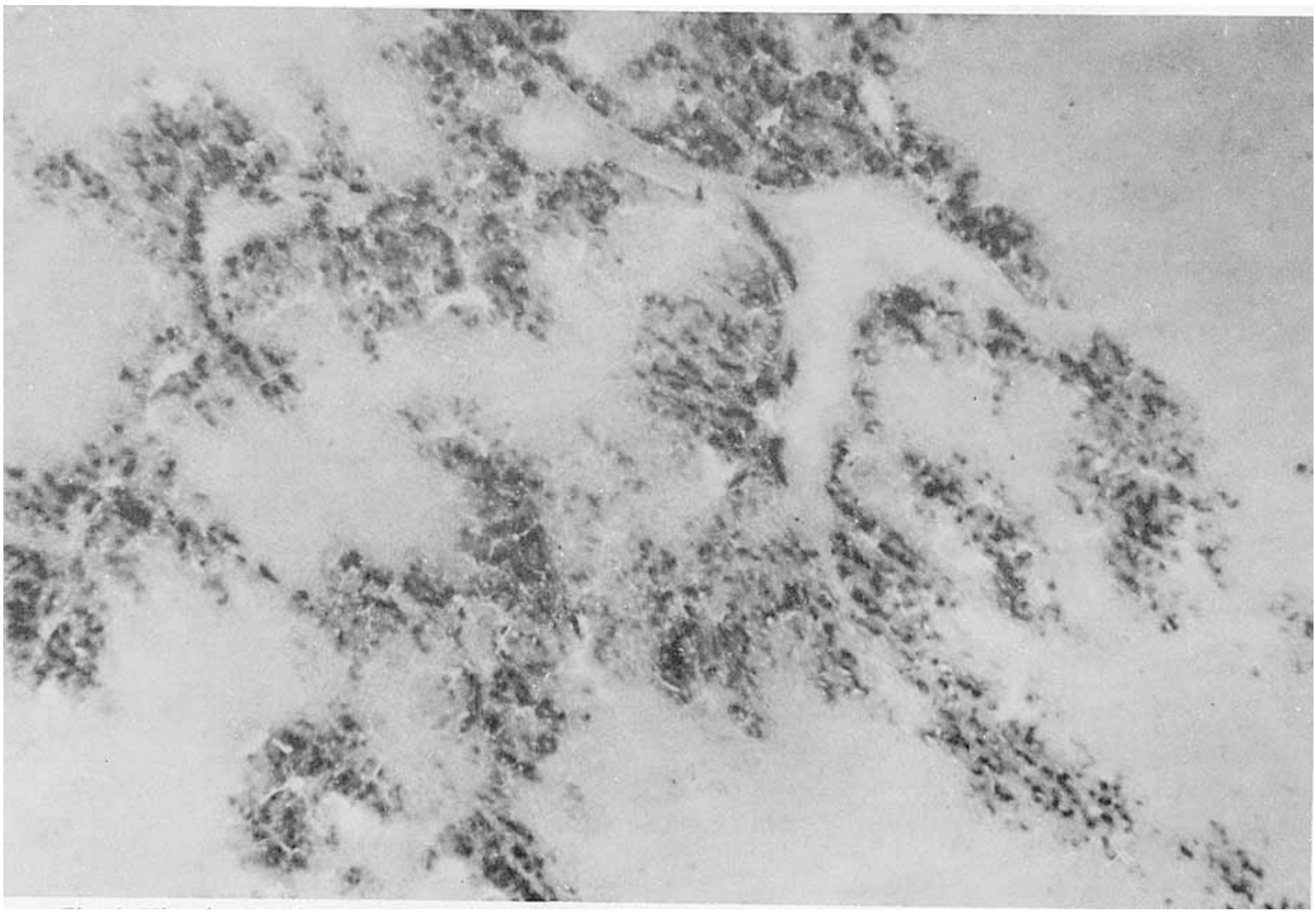

Fig. 5. Histochemical distribution of $\gamma$-glutamyltranspeptidase in the rat liver 30 days after portacaval shunt $(\times 57)$.

the result of an underlying "activating process." GGTP as a microsomal enzyme might react to various stimuli; since it has been demonstrated that it is susceptible to an activating action of ethanol and certain drugs, particularly barbituarates $(30,38)$. It cannot be deduced from our experiments whether the rise of enzyme activity after PCS can be attributed to a de novo synthesis of the enzyme-protein as has been observed for other enzymes. Thus the increased activity of tyrosine transaminase after PCS 
could be blocked by the administration of actinomycin $D$, suggesting a postshunt hepatic synthesis of the enzyme (25). This enzyme, however, is not elevated during life, but the level rises immediately after birth (18).
A high level of activity of GGTP has also been reported in transplantable chemically induced rat hepatomas which contain glycogen, produce bile, and have a high level of glucose-6-phosphatase (12). It has also been shown that the activity of GGTP was

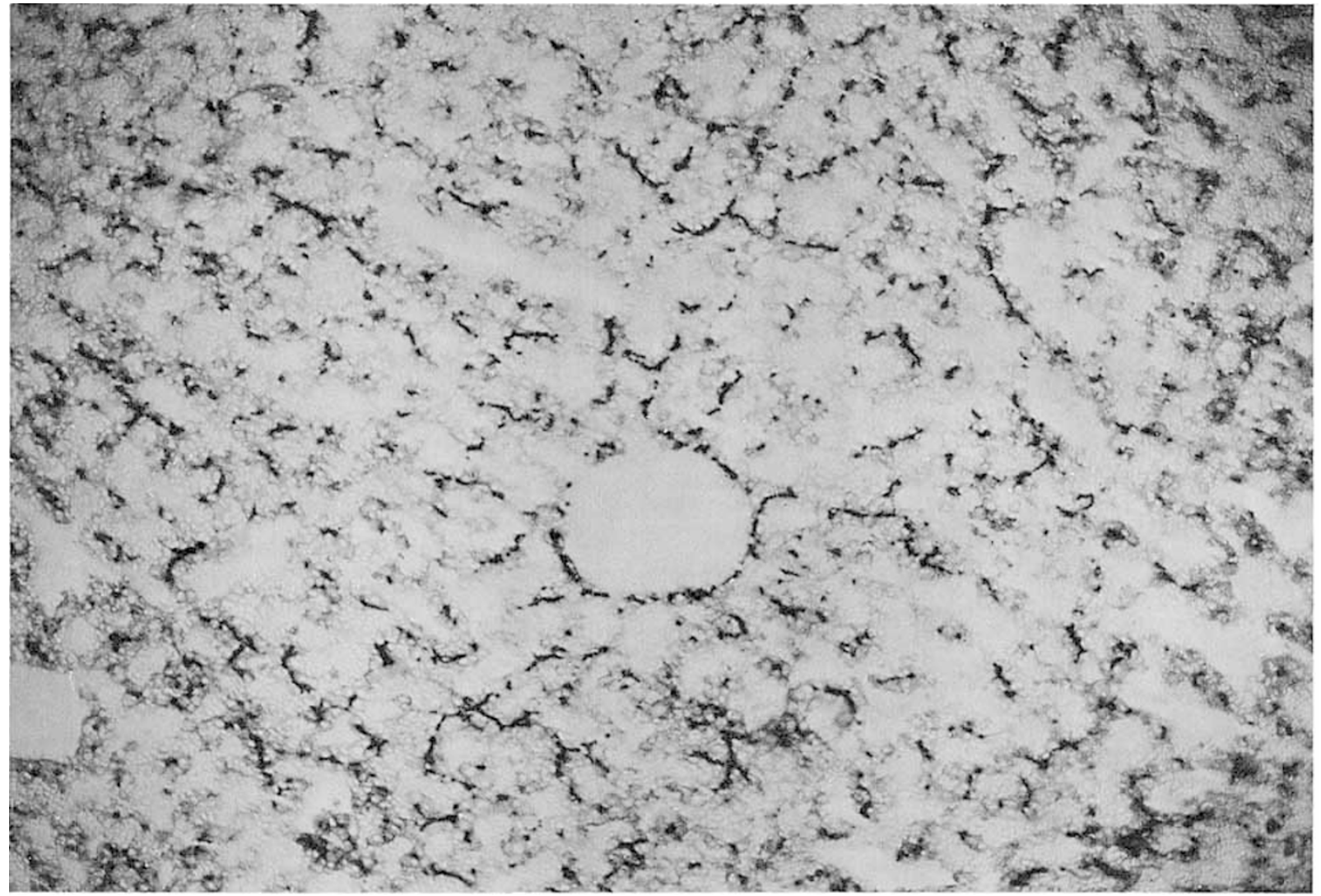

Fig. 6. Histochemical distribution of $\gamma$-glutamyltranspeptidase in the human fetal liver of 18 weeks' gestation $(\times \quad 94)$.

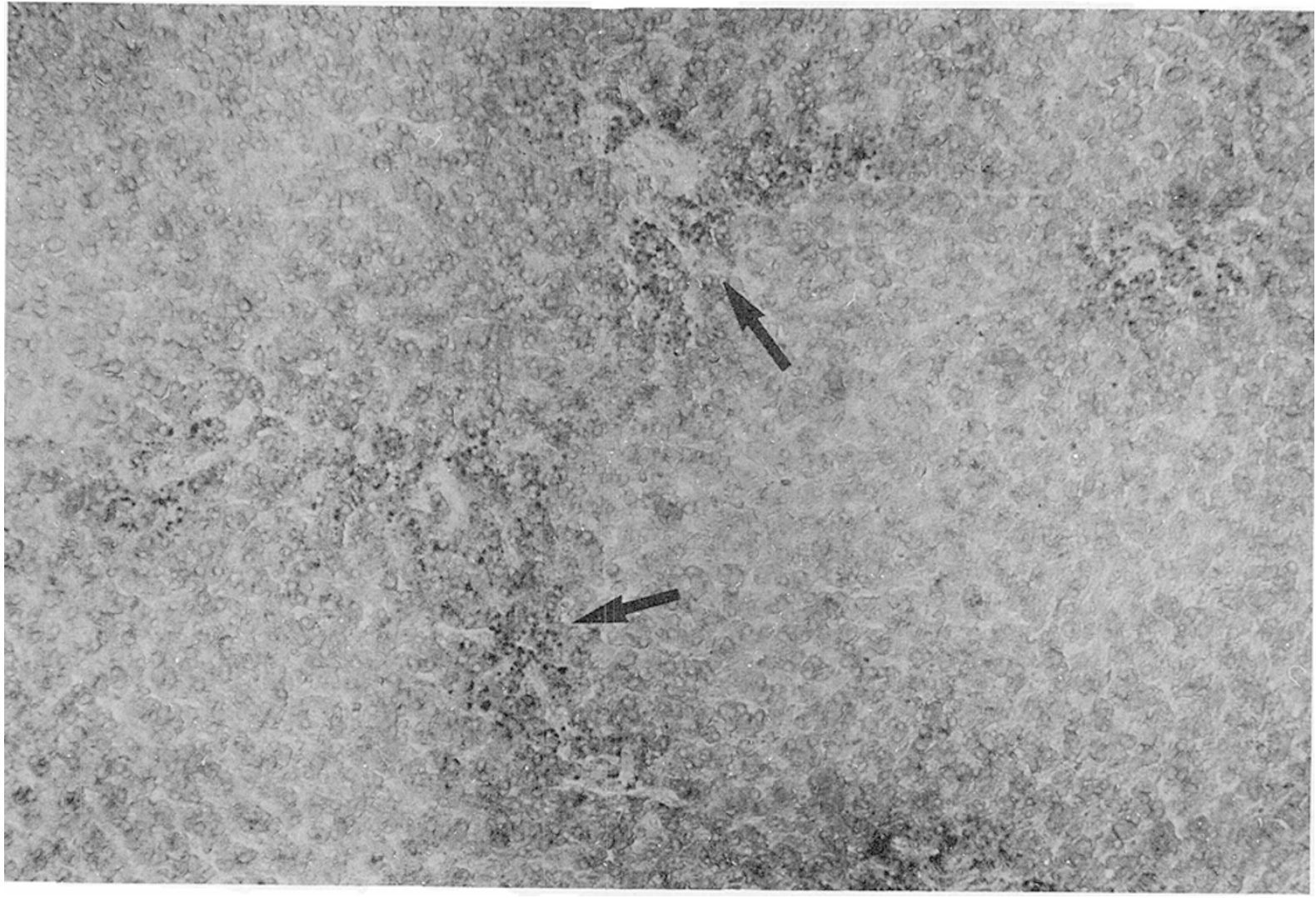

Fig. 7. Histochemical distribution of $\gamma$-glutamyltranspeptidase in the liver of a 3-month-old child ( $\times$ 57). 
closely related to the carcinogenic process independent of the length of administration of hepatotoxic carcinogens (11). In humans elevated GGTP activities have been measured in liver tissue affected with primary carcinoma (17). The elevated activity has been observed particularly in the hepatocytes surrounding the carcinomatous areas and may be due, according to these authors, to some unknown mechanism of enzyme induction by the tumor tissue. Humans with primary carcinoma of the liver regularly show elevated values of GGTP in serum $(17,32)$. The findings of high GGTP activities in transplantable, chemically induced rat hepatomas have been interpreted as a re-aquirement of a biochemical feature which predominates in the fetus but is repressed in adult animals (10). A similar mechanism could explain the elevation and the histochemical reappearance of hepatic GGTP activity after PCS in this study.

Meister (22) and Orlowski et al. (23) postulate that GGTP plays a key role in the $\gamma$-glutamyl cycle, which is responsible for the transport of aminacids into the cell. This transport mechanism may function in the kidney tubules, at the brain-cerebral spinal fluid barrier $(23)$, intestine $(2,4)$, and possibly also in hepatocytes of fetal animals, of rat hepatomas (12), and man. It could be speculated that the rapid growth of fetal liver as well as the underlying processes leading to the changes observed in hepatomas and after PCS create the need for a augmented amino acid transport.

The increased activity of GGTP after PCS might be associated with a derepression of an enzyme normally present only in fetal and neonatal rat liver. This observation raises the question of whether such a mechanism is limited to changes of this particular enzyme, which is involved mainly in transmembrane amino acid transport, to a few specific enzymes, or whether it represents a partial aspect of a generalized hepatic involvement.

\section{SUMMARY}

GGTP was studied in the liver of fetal, neonatal, and adult rats. The activity of the enzyme is high in the fetal rats and declines subsequently after birth to low values which, from the 10th day, are identical with those observed in adult animals. Compared with control and sham-operated animals, an increased activity of GGTP in the liver was observed in the rats submitted to an end-to-side portacaval shunt 10-30 days after the operation. These findings were confirmed by histochemical staining of the enzyme activity. The increase of GGTP activity after PCS may be interpreted as a sign of functional changes leading to a reappearance of an enzyme normally present only in fetal and neonatal liver.

\section{REFERENCES AND NOTES}

1. Assal, J. P., Levrat, R., Cahn, T., and Renold, A. E.: Metabolic consequences of portacaval shunting in the rat. Z. Gesamte Exp. Med., 154:87 (1971).

2. Auricchio, S., Ciccimarra, F.. Vegnente, A., Andria, G., and Vetrella, M.: Enzymatic activity hydrolyzing $\gamma$-glutamyl- $\beta$-naphthylamide in human intestine during adult and fetal life. Pediat. Res., 7: 95 (1973).

3. Baginski, S. F., Foa, P. P., and Jak, B.: Glucose-6-Phosphatase, In: H. U. Bergmeyer: Methoden der enzymatischen Analyse, Vol. 1, p. 839 (Academic Press, New York, 1970).

4. Cohen, M. I., Gartner, L. M., Blumenfeld, O. O., and Arias, I. M.: Gammaglutamyl transpeptidase: Measurement and development in guinea pig small intestine. Pediat. Res., 3: 5 (1969).

5. Colombo, J. P., and Bircher, J.: Acquisition of an embryonal biochemical feature in the rat liver after portacaval shunt. In Annual meeting of the European Society of pediatric Research, Sevilla [Abstr.]. (1973).

6. Colombo, J. P., and Bircher, J.: Acquisition of an embryonal biochemical feature in the rat liver after portacaval shunt. Experimentia, 29: 1232 (1973).

7. Colombo, J. P., Herz, R., and Bircher, J.: Liver enzymes in the eck fistula rat.
Enzyme, 14: 353 (1973).

8. Dawkins, J. R.: Biochemical aspects of developing functions in newborn mammafian liver. Brit. Med. Bull., 22: 227 (1966).

9. Du Bois, A. M.: C. M. Rouillier: In: The Embryonic Liver (Academic Press, New York, 1963).

10. Fiala, S., and Fiala, A. E.: Acquisition of an embryonal biochemical feature by rat hepatomas. Experimentia, 24:889 (1970).

11. Fiala, S., and Fiala, A. E.: Activation by chemical carcinogens of $\gamma$-glutamyl transpeptidase in rat and mouse liver. J. Nat. Can. Inst., Sl: 151 (1973).

12. Fiala, S., Fiala, A. E., and Dixon, B.: $\gamma$-Glutamyl transpeptidase in transplantable, chemically induced rat hepatomas and "spontaneous" mouse hepatomas. J. Nat. Can. Inst., 48: 1393 (1972).

13. Fisher, B., Fisher, E. R., and Lee, S.: Experimental evaluation of liver atrophy and portacaval shunt. Surg. Gynec. Obstet., 125: 1253 (1967).

14. Herz, R., Paumgartner, G., and Preisig, R.: Bile salt metabolism and bile formation in the rat with portacaval shunt. Eur. J. Clin. Invest., 4: 223 (1974).

15. Herz, R., Sautter, V., Robert F., and Bircher, J.: The eck fistula rat: Definition of experimental model. Eur. J. Clin. Invest., 4: 223 (1974).

16. Knox, W. E.: Enzyme Patterns in Fetal, Adult and Neoplastic Rat Tissues, p. 164 (S. Karger, Basel, 1972).

17. Kokot, F., Kuska, J., Grzybek, H., and Cekanski, A.: $\gamma$-Glutamyl transpeptidase in tumor diseases. Arch. Immunol. Ther. Exp., 13: 586 (1965).

18. Kretchmer, N.: Development biochemistry-a, relevant endeavor. Pediatrics, 46: $175(1970)$

19. Kyu, M. H., and Cavanagh, J. B.: Some effects of portacaval anastomosis in the male rat. Brit. J. Exp. Pathol., 51: 217 (1970).

20. Lowry, O. M., Rosenbrough, N. J., Farr, A. L., and Randall, R. J.: Protein measurement with the Folin phenol reagent. J. Biol. Chem., 193: 265 (1951).

21. Meister, A.: Biochemistry of Aminoacids, p. 621 (Academic Press, New York, 1965).

22. Meister, A.: On the enzymology of amino acid transport. Science, 180: 33 (1973).

23. Orlowski, M., Sessa, G., and Green, J. P.: $\gamma$-Glutamyl transpeptidase in brain capillaries: Possible site of blood-brain barrier for amino acids. Science, 184: 66 (1974).

24. Reichle, F. A., Brigham, M., Tyson, R. R., Reichle, R. M., Reilly, M., and Rosemund, G. P.: Serine metabolism after portacaval shunt. Arch. Surg., 100: $163(1970)$

25. Reichle, F. A., Brigham, M., Reichle, R. M., Reilly, M., Tyson, R. R., and Rosemund, G. P.: Effect of portacaval shunt on tyrosine metabolism. Arch. Surg., 105: 363 (1972).

26. Reichle, F. A., Brigham, M., Tyson, R. R., and Rosemund, G. P.: Histidine metabolism after portacaval shunt in the rat. J. Surg. Res., 8: 320 (1968).

27. Richterich, R.: Klinische Chemie: Theorie und Praxis, p. 49 (Karger Basel, 1971).

28. Richterich, R.: Klinische Chemie: Theorie und Praxis, p. 234 (Karger. Basel, 1971)

29. Richterich, R., and Cantz, B.: Normal values of plasma $\gamma$-glutamyl transpeptidase in children. Enzyme, 13: 257 (1972).

30. Rosalki, S. B., and Rau, D.: Serum $\gamma$-glutamyl transpeptidase activity in alcoholism. Clin. Chim. Acta, 39: 41 (1972).

31. Rubin, E.: Studies in hepatic injury induced by experimental portacival shunts. Israel J. Med. Sci., 4: 155 (1968).

32. Rutenburg, A. M., Pineda, E. P., Fischbein, J., and Goldbary, J. A.: A study of serum peptidases in anicteric patients with cancer. Cancer, 17: 881 (1964).

33. Rutenburg, A. M., Kim, H., Fischbein, J. W., Hanker, J. S., Wasserburg, H. L., and Seligman, A. M.: Histochemical and ultrastructural demonstration of $\gamma$-glutamyl transpeptidase activity. J. Histochem. Cytochem., 17: 517 (1969).

34. Swenzuk, A.: A soluble form of $\gamma$-glutamyl transpeptidase in human tissue. Clin. Chim. Acta, 14: 608 (1966).

35. Szasz, G.: $\gamma$-Glutamyl-transpeptidase. In: H. U. Bergmeyer: Methoden der enzymatischen Analyse, Vol. I, p. 733 (Academic Press, New York, 1970).

36. Wehling, W. E., Dewey, H. K., and Knox, W. E.: Cellular nuclei and DNA contents of rat tissues. Enzyme, 14:87 (1972/73).

37. Weibel, E. R., Stäubli, W., Gnägi, H. R., and Hess, F. A.: Correlated morphometric and biochemical studies on the liver cell. 1. Morphometric model, stereologic methods and normal morphometric data for rat liver. J. Cell Biol., 42: 68 (1969).

38. Whitfieid, J. B., Moss, D. W., Neale, G., Orme, M., and Breckenridge, A. Changes in plasma $\gamma$-glutamyl transpeptidase activity associated with alterations in drug metabolism in man. Brit. Med. J., 1: 316 (1973).

39. Süddeutsche Versuchstierfarm, Tuttlingen, German Federal Republic.

40. Courtesy of Dr. G. Molz.

41. Cyclo Chemical Corp., Los Angeles, Calif.

42. We would like to thank Mrs. M. Hagen, Mrs. M. Müller and Miss H. Dauwalder for the valuable technical assistance.

43. These investigations were supported by the Schweiz Nationalfonds zur Förderung der wissenschaftlichen Forschung, Project no. 3.1500.73.

44. Requests for reprints should be addressed to: J. P. Colombo, M. D., Department of Clinical Chemistry, Inselspital, 3010 Berne (Switzerland).

45. Accepted for publication August 19, 1975. 